\title{
Perspective: machines for RNAi
}

\author{
Yukihide Tomari and Phillip D. Zamore ${ }^{1}$ \\ Department of Biochemistry and Molecular Pharmacology, University of Massachusetts Medical School, \\ Worcester, Massachusetts 01605, USA
}

\begin{abstract}
RNA silencing pathways convert the sequence information in long RNA, typically double-stranded RNA, into 21-nt RNA signaling molecules such as small interfering RNAs (siRNAs) and microRNAs (miRNAs). siRNAs and miRNAs provide specificity to protein effector complexes that repress mRNA transcription or translation, or catalyze mRNA destruction. Here, we review our current understanding of how small RNAs are produced, how they are loaded into protein complexes, and how they repress gene expression.
\end{abstract}

Three questions have guided the study of RNA silencing (Box 1) for nearly a decade: What is the molecular nature of the silencing trigger? What are the silencing targets? And what proteins comprise the RNAi machinery? These questions continue to organize the study of RNA silencing, even as new questions emerge about its mechanism and how the pathway is woven into the broader fabric of cell metabolism and plant and animal development.

\section{Triggers and guides}

Silencing triggers are nucleic acids that initiate the assembly of protein-RNA complexes that repress expression of specific target genes by reducing their rates of transcription, the stability of their mRNAs, or the translation of their mRNAs into protein. Silencing triggers identify their nucleic acid targets by sequence-specific base pairing. The best studied silencing trigger is doublestranded RNA (dsRNA), which can be produced by bidirectional transcription, transcription of an inverted repeat or "hairpin" sequence, or physically introduced into cells by injection, soaking, or even feeding dsRNA-expressing bacteria (Kennerdell and Carthew 1998; Montgomery and Fire 1998; Tabara et al. 1998; Timmons and Fire 1998; Waterhouse et al. 1998; Clemens et al. 2000; Billy et al. 2001). Transgenes intended to generate only

[Keywords: Argonaute; Dicer; PTGS; RISC; RNA silencing; RNAi] ${ }^{1}$ Corresponding author.

E-MAIL phillip.zamore@umassmed.edu; FAX (508) 856-2003. Article and publication at http://www.genesdev.org/cgi/doi/10.1101/ gad.1284105.
Box 1. RNA silencing primer.

RNA silencing was first observed in plants (post-transcriptional gene silencing, PTGS) and fungi ("quelling"), where attempts to overexpress endogenous genes by introducing transgenic copies of the endogene instead blocked expression of both (Cogoni et al. 1996; Jorgensen 2003). In animals, RNA silencing was first reported when Guo and Kemphues (1995) used antisense RNA to block par-1 mRNA expression in Caenorhabditis elegans but found that the par-1 mRNA itself also repressed par-1. Their paradoxical observationsubsequently dubbed RNA interference (RNAi)-inspired the experiments of Fire, Mello, and colleagues (Fire et al. 1998), who showed that double-stranded RNA (dsRNA), was the trigger of gene silencing. RNAi is but one aspect of a larger web of sequence-specific, cellular responses to RNA known collectively as RNA silencing. All RNA silencing pathways are triggered by 21-27-nt-long "small RNAs" - a term that encompasses small interfering RNAs (siRNAs), repeat-associated small interfering RNAs (rasiRNAs), and micro RNAs (miRNAs). These silencing pathways share a common set of proteins that produce or amplify small RNAs and couple small RNAs to specific regulatory outcomes. Small RNAs guide RNA silencing effector complexes, like the RNA-induced silencing complex (RISC) (Hammond et al. 2000) or the RNA-induced initiation of transcriptional gene silencing (RITS) complex (Verdel et al. 2004). A member of the Argonaute family of proteins lies at the heart of all RNA silencing effector complexes (Tabara et al. 1999, 2002; Hammond et al. 2001; Hutvágner et al. 2001; Catalanotto et al. 2002; Martinez et al. 2002; Mourelatos et al. 2002; Diikeng et al. 2003; Shi et al. 2004). RNA silencing proteins, often called the "RNAi machinery", also include the multidomain ribonuclease III enzyme Dicer, which produces small RNAs and RNA-dependent RNA polymerases (RdRPs), which amplify silencing triggers (see Box 2).

sense or antisense RNA also silence gene expression, especially in plants (Baulcombe 1996, 2004; Jorgensen 2003). The copying of these transgene-encoded singlestranded RNAs into dsRNA is thought to convert them into silencing triggers (Jorgensen 2003; Baulcombe 2004). We do not understand how cells can distinguish between abundant cellular mRNAs, which do not trigger silencing, and aberrant RNAs, which do. Current data support a threshold sensing model, in which "aberrant" single- 
stranded RNA accumulates in vivo beyond some critical level, triggering its copying into dsRNA (Zamore 2001; Jorgensen 2003). The absence of in vitro systems that recapitulate RNA silencing triggered by single-stranded RNA has limited progress on this problem, which is central to silencing in nematodes, fungi, and plants, but does not seem to play a role in flies or mammals (Box 2).

The path from dsRNA trigger to silenced gene is now broadly outlined. The discovery that silencing is heritable in worms (Grishok et al. 2000) and can spread the

Box 2. Amplification of silencing triggers.

RNA silencing pathways can be divided into those that require RdRPs and those that do not. In Caenorhabditis elegans and fungi like Neurospora crassa and Schizosaccharomyces pombe, genes encoding RdRP enzymes are required for silencing (Cogoni and Macino 1999; Dalmay et al. 2000; Mourrain et al. 2000; Smardon et al. 2000; Sijen et al. 2001; Hall et al. 2002; Volpe et al. 2002). In plants, RdRPs are required for silencing initiated by single-stranded RNA triggers (Dalmay et al. 2000), but perhaps not for silencing triggered by dsRNA (Waterhouse et al. 1998). In C. elegans, dsRNA is thought to first be diced into rare primary siRNAs and then amplified by RdRP enzymes to create more abundant secondary siRNAs (Sijen et al. 2001). Two models have been proposed to explain the role of RdRPs. First, RdRPs might use primary siRNAs to prime the synthesis of dsRNA using the target mRNA itself as a template. Primed synthesis of dsRNA by RdRPs can lead to spreading, the production of siRNAs encoded by the target gene but not by the trigger RNA. Such spreading along the target should only occur $5^{\prime}$ to the dsRNA trigger, as is observed in worms (Sijen et al. 2001). In plants, however, siRNAs spread both $5^{\prime}$ and $3^{\prime}$ along the target, relative to the trigger RNA /Voinnet et al. 1998; Vaistij et al. 2002), hence the notion of an unprimed RdRP pathway, in which single-stranded RNA fragments are copied without the use of siRNA primers. Primed and unprimed RdRP activities have been detected for purified RdRP enzymes and in plant extracts (Schiebel et al. 1993a,b, 1998; Makeyev and Bamford 2002; Tang et al. 2003). Spreading of siRNAs is linked to systemic silencing, a phenomenon observed in worms and plants in which locally initiated silencing can be inherited or can spread systemically to distant parts of the organism (Boerjan et al. 1994; Fire et al. 1998). Recent evidence suggests that protein-bound siRNAs flowing through the vasculature cause systemic silencing in plants (Yoo et al. 2004). Thus, siRNAs function as both intracellular and extracellular signaling molecules.

RdRPs do not seem to play any role in the Drosophila and mammalian RNAi pathways, where amplification and spreading have not been detected in vivo, perhaps because no RdRP homologs are present in the genomes of flies or mammals (Celotto and Graveley 2002; Chiu and Rana 2002; Schwarz et al. 2002; Roignant et al. 2003). In this regard, the Drosophila and mammalian RNAi pathways resemble the miRNA pathway in plants, which does not involve RdRPs or spreading (Parizotto et al. 2004; Xie et al. 2004). The absence of an RdRP-dependent amplification step may explain the relatively short duration of RNAi in dividing cells in these organisms (Holen et al. 2002). For an alternative perspective, the reader should consult Lipardi et al. (2001). length of a branch through the vasculature of higher plants (Voinnet and Baulcombe 1997) suggested that the initial silencing trigger was converted into a stable specificity determinant, a novel intermediate with a structure or chemistry uniquely enabling it to target a gene for silencing. The work of plant virologists Hamilton and Baulcombe (1999) and of two teams of biochemists working with extracts of Drosophila cells (Hammond et al. 2000; Zamore et al. 2000) collectively demonstrated that the dsRNA is converted by endonucleolytic cleavage into a new class of intracellular signaling molecules, small interfering RNAs (siRNAs). These 21-25-nt double-stranded RNAs have a characteristic structure that reflects their production by the multidomain ribonuclease III (RNase III) enzyme, Dicer (Bernstein et al. 2001; Elbashir et al. 2001a,b; Ketting et al. 2001; Knight and Bass 2001; Xie et al. 2004). siRNAs and related small RNAs are the first class of RNA-based signaling molecules that couple an input-a single- or double-stranded RNA trigger-to a regulatory output, a reduction in gene expression (i.e., "silencing"). Moreover, the sequence and structure of a small RNA determines how it functions to effect silencing as well as the identity of its target genes.

The discovery that exogenous dsRNA is converted into siRNAs led directly to the recognition that microRNAs (miRNAs) and endogenous siRNAs regulate endogenous gene expression via the RNAi pathway (Fig. 1; Lee et al. 1993; Pasquinelli et al. 2000; Reinhart et al. 2000, 2002; Aravin et al. 2001, 2003; Lagos-Quintana et al. 2001, 2002, 2003; Lau et al. 2001; Lee and Ambros 2001; Llave et al. 2002a; Mourelatos et al. 2002; Reinhart and Bartel 2002; Brennecke and Cohen 2003; Brennecke et al. 2003; Chen 2004; Chen et al. 2004; Dostie et al. 2003; Johnston and Hobert 2003; Lim et al. 2003a,b; Palatnik et al. 2003; Chang et al. 2004). miRNAs are cousins of siRNAs: They are endogenous small RNA guides that repress the expression of target genes. miRNAs differ from siRNAs in their biogenesis, not in their functions (Hutvágner and Zamore 2002; Ambros et al. 2003; Aukerman and Sakai 2003; Chen 2004; Chen et al. 2004; Doench et al. 2003; Saxena et al. 2003; Zeng et al. 2003; Yekta et al. 2004). Like siRNAs, plant and animal miRNAs can direct cleavage of their mRNA targets when the two are extensively complementary (Hutvágner and Zamore 2002; Llave et al. 2002b; Tang et al. 2003; Xie et al. 2003; Zeng and Cullen 2003; Mallory et al. 2004; Okamura et al. 2004; Yekta et al. 2004), but repress mRNA translation when they are not (Olsen and Ambros 1999; Chen 2004; Doench et al. 2003; Saxena et al. 2003; Zeng et al. 2003; Doench and Sharp 2004). The sequence of a miRNA or an siRNA may determine how effectively it directs cleavage or translational repression.

Both siRNAs and miRNAs can also trigger methylation of the DNA of protein-coding genes that share their sequence in plants (Zilberman et al. 2003; Bao et al. 2004) and perhaps even in mammals (Kawasaki and Taira 2004; Morris et al. 2004). siRNAs can direct the construction of repressive heterochromatin, especially centromeric heterochromatin (Shiu et al. 2001; Hall et 
A

A miRNA biogenesis

B

siRNA biogenesis

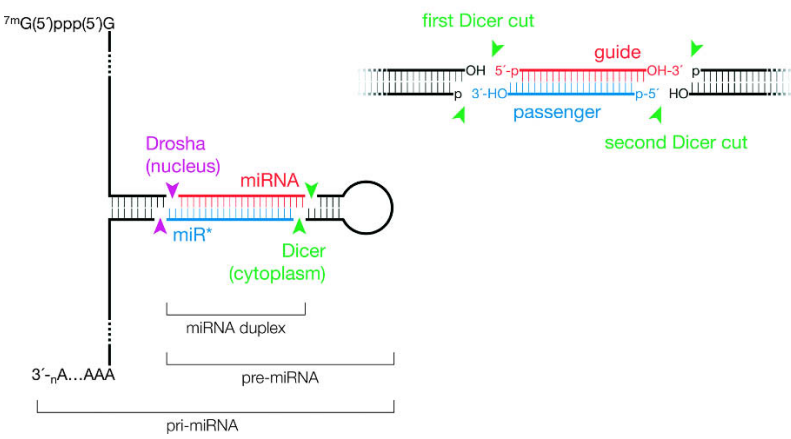

Figure 1. Small RNA biogenesis in animals. $(A)$ miRNA are produced by the successive actions of two RNase III ribonucleases. After their transcription by RNA polymerase II, primary miRNA (pri-miRNA) are cleaved in the nucleus by Drosha, likely as a heterodimeric complex with the dsRNA-binding protein, Pasha, which forms the whimsically named microProcessor complex. Drosha cleavage generates the pre-miRNA, which binds Exportin 5 and is exported to the cytoplasm. In the cytoplasm, Dicer is thought to bind the base of the pre-miRNA stem defined in the nucleus by Drosha. Dicer cleavage liberates a duplex comprising the miRNA and $\mathrm{miR}^{\star}$ strands of the premiRNA. The miRNA must then be unwound and selectively incorporated into RISC by the miRNA-specific RISC assembly machinery. $(B)$ Long dsRNA is a substrate for Dicer, but not for Drosha. Dicer must make two successive pairs of cuts to yield an siRNA duplex. Dicer is thought to preferentially initiate dsRNA cleavage at the ends of dsRNA, a phenomenon that sometimes produces a phased string of siRNAs along the dsRNA. The siRNA-specific RISC assembly machinery selectively loads the guide strand into RISC; the passenger strand is degraded.

al. 2002; Mochizuki et al. 2002; Volpe et al. 2002; Schramke and Allshire 2003; Liu et al. 2004b; Noma et al. 2004; Verdel et al. 2004). As a class, miRNA and siRNA guide strands are functionally indistinguishable, but it is still unknown if all miRNAs and siRNA sequences are capable of effectively guiding all RNA silencing functions.

Cellular miRNAs are derived from long primary RNAs (pri-miRNAs) transcribed by RNA Polymerase II (Bracht et al. 2004; Cai et al. 2004; Lee et al. 2004a; Parizotto et al. 2004). Animal viruses also encode miRNAs (Bennasser et al. 2004; Pfeffer et al. 2004); these may be transcribed by RNA Polymerase II or III. pri-miRNAs contain stem-loop structures that harbor the miRNA in the $5^{\prime}$ or 3 ' half of the stem (Fig. 1; Lee et al. 2002). In animals, the stem-loops are $70 \mathrm{nt}$ long, and Drosha, a nuclear RNase III endonuclease, liberates the stem-loop from the primary transcript to yield a pre-miRNA (Lee et al. 2003). The pair of cuts made by Drosha establishes one end of the miRNA (Basyuk et al. 2003; Lee et al. 2003). In these efforts, Drosha collaborates with a double-stranded RNA-binding protein, called Pasha in flies and DGCR8 in humans (Denli et al. 2004; Gregory et al. 2004; Han et al. 2004; Landthaler et al. 2004). Pasha is required for Drosha function, but why is not yet known. The pre-
miRNA liberated by Drosha is exported from the nucleus by the protein Exportin 5 (Yi et al. 2003; Bohnsack et al. 2004; Lund et al. 2004; Zeng and Cullen 2004), then cut by Dicer in the cytoplasm to produce the mature miRNA (Grishok et al. 2001; Hutvágner et al. 2001; Ketting et al. 2001; Park et al. 2002). In some organisms, such as worms and people, the same Dicer that makes siRNAs processes pre-miRNA; in plants and flies, different Dicer paralogs make siRNAs and miRNA (Lee et al. 2004b; Xie et al. 2004). In plants, a nuclear Dicer may double as both Drosha and Dicer (Finnegan et al. 2003; Papp et al. 2003; Kurihara and Watanabe 2004; Xie et al. 2004).

All current evidence suggests that both miRNAs and siRNAs are born double-stranded, but accumulate in functional complexes as single-strands. The most compelling evidence that miRNAs initially comprise two strands is that miRNA biogenesis can be blocked in both plants and animals by the viral protein p19, a suppressor of the RNA silencing defenses that plants mount against viral infection. p19 binds double-stranded siRNA-like structures but not single-stranded RNAs (Vargason et al. 2003; Ye et al. 2003; Lakatos et al. 2004). Thus, the simplest explanation for 19 protein blocking miRNA function is that miRNAs are transiently double-stranded. Each miRNA or siRNA duplex can potentially yield two single-stranded 21-nt RNAs capable of directing RNA silencing, so new vocabulary is needed to describe the strands. Only one of the two possible small RNAs residing in the stem of a pre-miRNA usually accumulates in vivo; this is the mature miRNA. The underrepresented strand is the miR* ("meer star"). (The corresponding strands of an siRNA are the guide strand, which accumulates in RISC, and the passenger strand, which is largely destroyed.) Consistent with the view that miRNA are initially born as duplexes, from which the mature miRNA is selected and the $\mathrm{miR}^{\star}$ strand degraded, p19 protein and another suppressor of RNA silencing, p21 protein, stabilize $\mathrm{miR}^{\star}$ strands and lead to the accumulation of $\mathrm{miR} / \mathrm{miR}^{\star}$ duplexes in plants (Chapman et al. 2004; Dunoyer et al. 2004).

\section{The hallmarks of highly effective siRNA}

In 2003, two types of experiments to understand siRNA function converged on a single insight: siRNA structure and sequence determine which siRNA strand enters RISC as the guide strand and which is excluded from RISC, becoming the passenger strand. Several groups, but most comprehensively, the team of Khvorova and colleagues, used informatic methods to understand why some siRNAs successfully knock-down their intended mRNA targets while others do not (Aza-Blanc et al. 2003; Khvorova et al. 2003). They compared the thermodynamic profiles for hundreds of siRNAs-active and inactive-in order to decipher the signature of siRNAs that successfully function in the RNAi pathway in cultured mammalian cells. Thermodynamic profiles of siRNAs provide a graphical representation of how tightly base 
paired one siRNA strand is to its complement at each position of the 19-bp helix that links the two strands. The local thermodynamic stability of nucleic acid helices is a function of the base pairs flanking an individual G:C or A:U base pair in an RNA helix. Thus, a "nearestneighbor" analysis can predict the local stability at each position in an siRNA (Xia et al. 2001).

Simultaneously, our own laboratory used in vitro biochemistry in Drosophila embryo lysates to understand how RISC, which contains single-stranded siRNA, is produced from siRNA duplexes (Schwarz et al. 2003). The biochemical and informatics efforts reached a single conclusion: The sequence and structure of an siRNA determines which of its two strands participates in the RNA silencing pathway. Consequently, some siRNAs appear inactive in vivo because the wrong strand has entered the RNAi pathway. Strategies for designing siRNAs that load the useful strand (the antisense strand) into RISC have been reviewed elsewhere (Silva et al. 2003; Gong and Ferrell 2004), and we implore readers to explore these "design rules" before synthesizing siRNAs to reduce expression of a favorite gene (Khvorova et al. 2003; Amarzguioui and Prydz 2004; Hohjoh 2004; Naito et al. 2004; Reynolds et al. 2004; Ui-Tei et al. 2004; Yiu et al. 2005). siRNAs designed to load one strand into RISC to the near exclusion of the other are called "functionally asymmetric."

The informatics and biochemical studies also revealed a structural feature of functional siRNAs: Their ends look like those of $\mathrm{miRNA} / \mathrm{miR}^{\star}$ duplexes (Khvorova et al. 2003). The strand with the less-tightly base-paired 5' end usually corresponds to the mature miRNA, whereas the $\mathrm{miR}^{\star}$ strand has the more-tightly paired 5' end and is degraded (Schwarz et al. 2003; Krol et al. 2004).

\section{Building the RNAi effector complex}

The central step of RISC assembly is the loading of one of the two siRNA strands into RISC. RISC assembly has only been studied in vitro for Drosophila, so we do not yet know if data from flies can be generalized to other organisms. In flies, siRNA and miRNA are produced by distinct Dicer enzymes; Drosophila Dcr-1 produces miRNAs, whereas Dcr-2 makes siRNAs (Lee et al. 2004b). Dcr-2 also acts to load one of the two siRNA strands into RISC. The function of Dcr-2 in RISC assembly is genetically distinct from its more famous role in producing siRNAs (Lee et al. 2004b). Human Dicer may also function in loading siRNA into RISC, because siRNA do not elicit silencing in human cells lacking Dicer (Doi et al. 2003). In contrast, siRNAs function to reduce target gene expression in Dicer knockout ES cells (Kanellopoulou et al. 2005). Perhaps Dicer is only required in human cells to load Ago2-containing RISC complexes, much as Dcr-2 is required only to load Ago2 in Drosophila.

Two similar ordered pathways have been proposed for Drosophila RISC assembly (Pham et al. 2004; Tomari et al. 2004a). In one scheme, RISC assembly begins with the binding of the double-stranded siRNA to as yet uni- dentified protein(s) to form "complex B" (Tomari et al. 2004a). In vitro, complex B is a kinetic precursor to a more well understood complex, the RISC-loading complex (RLC; formerly "complex A"). While the case for complex B as an early intermediate in the RISC assembly pathway is incomplete, the idea that the RLC plays a central role in loading siRNA into RISC is well supported (Tomari et al. 2004a,b). The RLC contains the proteins Dcr-2 and its partner R2D2, which contains tandem dsRNA-binding domains (Tomari et al. 2004a,b). Both Dcr-2 and R2D2 are needed for RNAi in vivo (Lee et al. 2004b; Liu et al. 2003; Pham et al. 2004), for the formation of the RLC (Tomari et al. 2004a), and for siRNA unwinding (Tomari et al. 2004b). The RLC contains both double-stranded siRNA and a smaller amount of singlestranded siRNA, suggesting that siRNA unwinding initiates in this complex (Tomari et al. 2004b). In Caenorhabditis elegans, Dicer and the R2D2-like protein RDE-4 have been detected in a complex with RDE-1, an Argonaute protein, so Dicer may also function in RISC assembly in worms, although RDE-4 does not appear to bind siRNA, unlike R2D2 (Tabara et al. 2002).

Sontheimer and colleagues propose a RISC assembly pathway that begins with complex $\mathrm{R} 1$ and proceeds via complex R2 to RISC (Pham et al. 2004). Like the RLC, complexes R1 and R2 contain Dcr-2 and R2D2. Lysates prepared from embryos lacking Dcr-2 make neither R1 nor R2, whereas embryos lacking Dcr-1, which is required for the production of miRNA but not siRNA, assemble R1 but not R2 (Lee et al. 2004b; Pham et al. 2004). Which if either of these two complexes corresponds to the RLC? The molecular weight of complex R1 and its requirement for 5' phosphates but not ATP suggest that it is the same complex detected earlier as a RISC precursor (Nykänen et al. 2001), and recent data suggest that both complexes correspond to the Dcr-2/R2D2 heterodimer bound to siRNA (J.W. Pham and E.J. Sontheimer, pers. comm.). Complex R2 might then correspond to the RLC, whose assembly requires both the Dcr-2/ R2D2 heterodimer and ATP. However, Complex R2 forms even when ATP is depleted (Pham et al. 2004).

The requirement for Dcr-1 for the formation of complex R2 is intriguing. Extracts from Drosophila S2 cells in which Dcr-1 has been depleted by RNAi still dice long dsRNA into siRNAs (Liu et al. 2003). In these lysates, Dcr-2 and R2D2 levels are normal. Yet, genetic depletion of Dcr-1 in Drosophila embryos reduces the efficacy of RNAi triggered by either long dsRNA or siRNA. Perhaps other components of the RNAi pathway are destabilized by the absence of Dcr-1, rather than Dcr-1 itself being required for siRNA-guided RNAi. When lysates are programmed with exogenous siRNA, Dcr-1, Dcr-2, and R2D2 cosediment as an 80S complex, suggesting they are present in a holo-RISC "assemblosome" that may load both siRNA and miRNA into RISC (Pham et al. 2004). Consistent with this view, the core RISC protein Ago2 and the auxiliary factors dFMR1 (also known as dFXR) TSN and VIG cofractionate with the 80S complex. The large size of holo-RISC may reflect the association of RISC with ribosomes. In fact, the Drosophila RISC com- 
ponent dFMR 1 interacts directly with the ribosomal proteins L5 and L11 (Ishizuka et al. 2002).

In lysates to which no siRNA has been added, Dcr-1, Ago2, dFMR1, TSN, and VIG all cosediment with the $80 S$ complex, but not Dcr-2 and R2D2. Why is the Dcr2/R2D2 heterodimer present in holo-RISC only when exogenous siRNA is present? Perhaps endogenous small RNAs, such as miRNAs, are produced and assembled into RISC in vivo in the holo-RISC, but siRNAs are generated separately from exogenous dsRNA triggers by the free Dcr-2/R2D2 heterodimer or by the larger, Dcr-2/ R2D2-containing RLC (Fig. 2).

As unwinding of siRNA proceeds, the Dcr-2/R2D2 heterodimer, probably in the RLC, is exchanged for the core RISC protein, Ago2 (Tomari et al. 2004b). Ago2 is not thought to be a component of the RLC, because the RLC forms in its absence. However, the RLC formed in lysates lacking Ago2 does not contain any singlestranded siRNA (Tomari et al. 2004b) because Ago2 is required for siRNA unwinding (Okamura et al. 2004). Moreover, Dcr-2 and R2D2 remain stably bound to the siRNA in the absence of Ago2, as if Ago2 is required for their release (Tomari et al. 2004b). Given that the Piwi domain of human Ago2 and the RNase III domain of human Dicer interact directly (Tahbaz et al. 2004), the Dcr-2/R2D2 heterodimer containing siRNA may be recruited to the holo-RISC by its binding Ago2. Docking of Dcr-2 with Ago2 may deliver the siRNA products of an

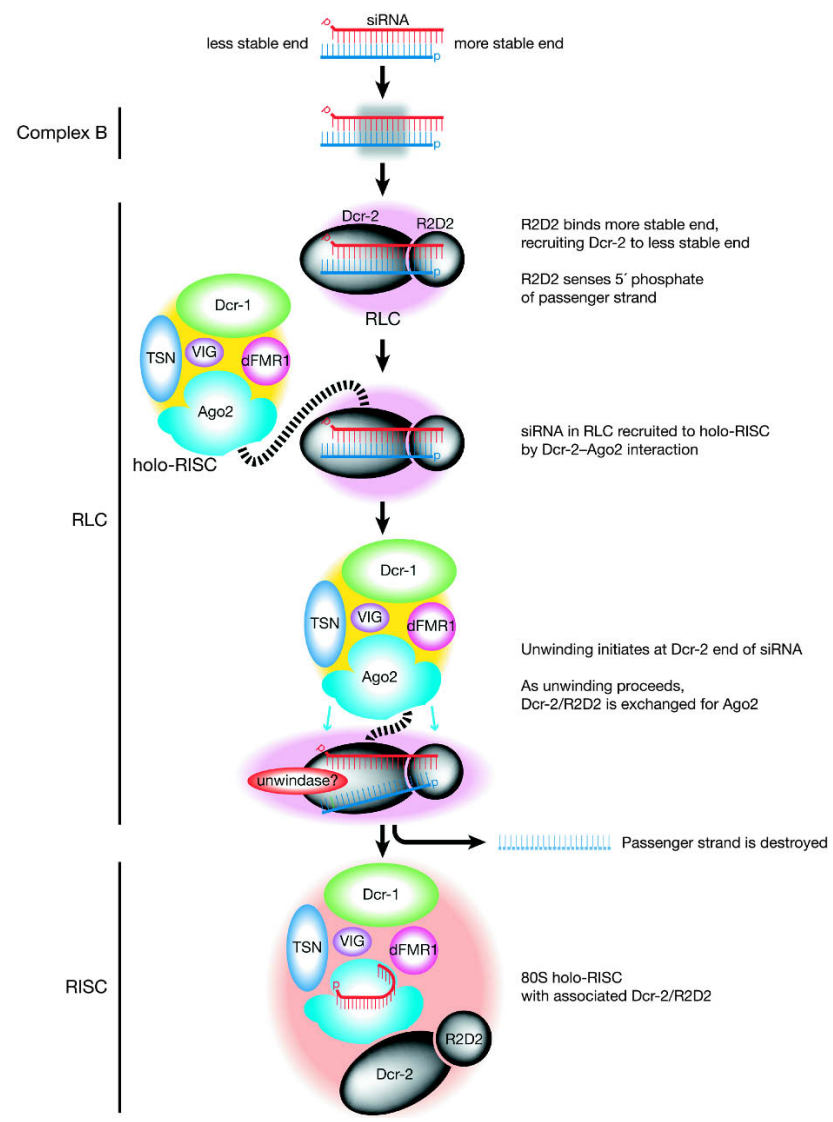

Figure 2. The RISC assembly pathway for siRNA in flies. exogenous dsRNA to the holo-RISC, perhaps changing the conformation of Ago2, Dcr-2, R2D2, or even the siRNA, thereby initiating unwinding.

Beyond its role in making siRNA, the Dcr-2/R2D2 heterodimer appears to sense siRNA thermodynamic asymmetry, because the orientation of these proteins on the siRNA duplex reflects which strand is incorporated into RISC (Tomari et al. 2004b). For functionally asymmetric siRNAs, the orientation of the heterodimer on the siRNA is determined largely by R2D2, which prefers to bind the siRNA end with greater doublestranded RNA character (Fig. 2). R2D2 binds more strongly to $5^{\prime}$ phosphorylated siRNA ends (Tomari et al. $2004 \mathrm{~b}$ ), while the presence of a $5^{\prime}$ phosphate does not influence Dcr-2 binding (Fig. 2; Pham et al. 2004; Tomari et al. 2004b). Thus, R2D2 also acts to authenticate siRNAs as products of Dicer, which leaves 5' phosphates on both strands (Elbashir et al. 2001a). The preference of R2D2 for 5' phosphorylated siRNA may indicate that R2D2 directly contacts the phosphate group-as has been observed for the siRNA-binding protein p19 (Vargason et al. 2003) —or may simply reflect the stabilizing effect of a 5' phosphate on RNA:RNA helices (Freier et al. 1983).

Flies lacking Dcr-2 or R2D2 show no major developmental defects (Liu et al. 2003; Lee et al. 2004b), suggesting that these proteins are not required for the biogenesis or function of miRNAs, many of which have essential developmental roles. In worms, the R2D2 homolog RDE-4 and the Argonaute protein RDE- 1 are required for silencing responses to exogenous dsRNA, but not for miRNA-directed pathways (Tabara et al. 1999). By keeping the production and assembly of siRNA into RISC separate from the miRNA pathway, worms and flies may prevent exogenous dsRNA triggers from competing with the developmentally essential miRNA pathway for RISC components. The miRNA and siRNA pathways are similarly distinct in plants (Vazquez et al. 2004; Xie et al. 2004). Yet, the biogenesis of miRNA is well explained by postulating an R2D2-like sensor for miRNA/miR* duplex thermodynamic asymmetry. What then senses the asymmetry of miRNA duplexes? Mammalian cells contain a single Dicer, which generates both miRNA and siRNA. An R2D2-like partner for human Dicer remains to be identified, but could conceivably act as a sensor for both siRNA and miRNA duplex asymmetry. However, flies have two Dicers. Perhaps Dcr-1 alone senses miRNA duplex asymmetry. Unlike Dcr-2, whose PAZ domain has drifted from the canonical sequence, Dcr-1 has a canonical PAZ domain. The PAZ motif is thought to bind single stranded RNA (Lingel et al. 2003; Song et al. 2003; Yan et al. 2003; Lingel et al. 2004; Ma et al. 2004). Thus, Dcr-1 might capture the end of the miRNA duplex that has more single-stranded character. Alternatively, Dcr-1 may have a yet-to-be-identified dsRNAbinding protein partner. An R2D2-like protein, Pasha, copurifies with Drosha, the ribonuclease III enzyme that cleaves pre-miRNA from their primary transcripts and thus defines one of the two ends of each miRNA (Fig. 1; Denli et al. 2004; Gregory et al. 2004; Han et al. 2004; 
Landthaler et al. 2004), but Drosha and Pasha are believed to function in the nucleus, whereas miRNA loading into RISC is thought to be cytoplasmic.

\section{Does Dicer release siRNAs, only to rebind them?}

If the Dcr-2/R2D2 heterodimer acts both in siRNA production from long dsRNA and in choosing which siRNA strand is assembled into RISC, do siRNAs fall off Dicer after they are made and then rebind, or does Dicer hold onto an siRNA after dicing, loading it directly into RISC? Since Dicer seems to pay no heed to siRNA thermodynamic asymmetry when producing siRNAs, siRNAs can be generated in two orientations relative to their thermodynamics: with their more weakly paired 5 ' end facing forward with respect to the end of the dsRNA where Dicer is thought to initiate (Elbashir et al. 2001a; Zhang et al. 2002, 2004), or with this 5' end facing backwards. Yet, the orientation of the Dcr-2/R2D2 heterodimer in the RLC is fixed by thermodynamic differences in the ends of an siRNA duplex. What is the fate of an siRNA that is made "backwards" with respect to its thermodynamic asymmetry and therefore backwards relative to its orientation within the Dcr-2/R2D2 heterodimer in the RLC? If such an siRNA has an opportunity to leave Dicer, then rebind in the "forward" direction, then even "backwards" siRNAs could enter the RISC loading pathway. Recently, Crété and colleagues (Vazquez et al. 2004) discovered an example of such a backwards siRNA in plants. They identified small RNAs arising from the intron of the gene At2g27400, which regulate expression of at least five other protein coding genes. Remarkably, siRNA production from At2g27400 is phased. The phasing of the siRNAs, with one siRNA every $21 \mathrm{nt}$, suggests that the entire cluster is made by Dicer moving in one direction. Only one of the two predicted strands of each of these siRNAs can be detected in vivo, generally in the forward direction. But for one siRNA, only the reverse strand accumulates in vivo. The relative thermodynamic stabilities of the $5^{\prime}$ ends of each siRNA accurately predict why most of the siRNAs accumulate as forward strands, but the one accumulates in the reverse orientation. The simplest explanation for the data is that each siRNA dissociates from the Dicer active site soon after it is produced, its thermodynamics are evaluated by the RNA silencing machinery, and then one strand is selectively loaded into RISC and the other strand destroyed. Khvorova et al. (2003), interpreting the data of Carrington and coworkers (Llave et al. 2002a), reached a similar conclusion for siRNAs generated in vivo in plants into which exogenous long dsRNA was introduced.

Dcr-2 alone can dice long dsRNA but does not stably bind siRNA, whereas the Dcr-2/R2D2 heterodimer binds siRNA tightly (Liu et al. 2003; Tomari et al. 2004b). These data suggest that siRNA are free to leave Dcr-2 after they are produced. They also suggest that siRNAs may subsequently be recaptured by the Dcr-2/R2D2 heterodimer via R2D2 binding siRNA. siRNAs inhibit Dcr-2 activity in cell lysates (Tang et al. 2003), suggest- ing that after the Dcr-2/R2D2 heterodimer has re-engaged an siRNA, it cannot interact with long dsRNA until it finishes loading the siRNA into RISC. The notion that siRNAs are made by Dicer, released, then bound again by the Dcr-2/R2D2 heterodimer is also consistent with the accumulation of free, double-stranded siRNAs observed when siRNAs are generated from long dsRNA in vitro in Drosophila embryo lysates (Nykänen et al. 2001), and with the ability of the double-stranded siRNA-binding protein, p19, to block RNAi initiated by long dsRNA in vivo in both plants and in cultured human cells (Chapman et al. 2004; Dunoyer et al. 2004; Lakatos et al. 2004). p19 protein also blocks RNAi initiated by long dsRNA or by siRNAs in vitro in Drosophila embryo lysates, but does not disrupt the function of Dicer in producing siRNAs or interfere with the activity of mature RISC in cleaving target RNA (Lakatos et al. 2004).

\section{RISC function}

Once loaded into RISC, small RNAs guide at least three distinct modes of silencing. In the RNAi pathway, small RNAs direct RISC to cut target RNAs. Cleavage by RISC requires $\mathrm{Mg}^{2+}$, leaves $3^{\prime}$ hydroxy and 5' phosphate termini, and is inhibited by phosphorothioates at the scissile phosphate, all hallmarks of a role for $\mathrm{Mg}^{2+}$ in catalysis. (Martinez and Tuschl 2004; Schwarz et al. 2004). Cleavage is thought to be catalyzed by the Piwi domain of a subclass of Argonaute proteins. This domain is a structural homolog of RNase $\mathrm{H}, \mathrm{a} \mathrm{Mg}^{2+}$-dependent endoribonuclease that cleaves the RNA strand of RNADNA hybrids (Liu et al. 2004a; Song et al. 2004). Unlike RNase H, each cleavage-competent RISC can break only one phosphodiester bond (the "scissile phosphate") in its RNA target (Elbashir et al. 2001a,b). RISC is a multipleturnover enzyme; the siRNA guide delivers RISC to the RNA target, the target is cleaved, then the siRNA departs intact with RISC (Hutvágner and Zamore 2002; Haley and Zamore 2004; Martinez and Tuschl 2004).

The first position of a small RNA in RISC does not to contribute to binding, as was first noted in studies designed to predict miRNA targets (Enright et al. 2003; Lewis et al. 2003; Stark et al. 2003). Instead, bases 2-8 form a "seed" that can be used computationally to pair miRNA with target candidates. The preeminent role of these bases was first proposed by Lai (2002), who noted that bases $2-8$ of many miRNAs were complementary to conserved sequence elements in the $3^{\prime}$ untranslated regions (UTRs) of post-transcriptionally repressed mRNAs in flies. It is now clear that most of the binding energy that tethers RISC to a target RNA comes from bases in the 5' half of the small RNA (Doench and Sharp 2004; Haley and Zamore 2004). This is a key difference between siRNAs or miRNAs and antisense oligonucleotides, where all bases contribute equally to specificity. In fact, complete pairing of the 3' half of an miRNA or siRNA to its target RNA is not required for translational repression, provided that multiple small RNAs are bound to the target (Doench and Sharp 2004), nor for 
target mRNA destruction, if the bases surrounding the scissile phosphate can form an A-form helix locally (Haley and Zamore 2004). Technologically, this means that most active siRNAs will not only down-regulate their intended mRNA targets but also reduce expression of other mRNAs possessing partial complementarity to the siRNA guide strand (Jackson et al. 2003). Solving this vexing siRNA "off-target" problem will most likely require modifying siRNA structure or sequence to maximize affinity for the target while reducing off-target binding, as well as the use of the lowest possible siRNA dose, so as to increase the discrimination between the desired target knock-down and undesirable "off-target" effects.

\section{A two-state model for Argonaute function}

Why do the $5^{\prime}$ nucleotides of an siRNA contribute disproportionately to target binding? Why don't the $3^{\prime}$ nucleotides contribute more binding energy? Figure 3 suggests a mechanism by which different regions of the siRNA guide strand or mature miRNA can make distinct contributions to small RNA function. This "two-state" model envisions that the $3^{\prime}$ end of an siRNA or miRNA is tightly bound to an Argonaute protein, the core constituent of the RISC. The small RNA is drawn with its $3^{\prime}$ end embedded in the PAZ domain. Cross-linking experiments suggest that in Drosophila siRNAs bind Ago2 through their $3^{\prime}$ ends (Tomari et al. 2004b), and structural studies make the Argonaute PAZ domain the best candidate for this binding (Lingel et al. 2003, 2004; Song et al. 2003; Yan et al. 2003; Ma et al. 2004). The siRNA would then extend along the positively charged binding cleft predicted by the structure of the Pyrococcus furiosus Agonaute protein (Song et al. 2004), with its 5' phosphate resting in a pocket within or near the Piwi domain (Parker et al. 2004). In fact, Barford and colleagues (Parker et al. 2004) propose that a divalent cation in a conserved region of the Piwi domain may mark the site of phosphate recognition. Such a phosphate-binding pocket is predicted because the identity of the scissile phosphate on the target RNA is measured from the $5^{\prime}$

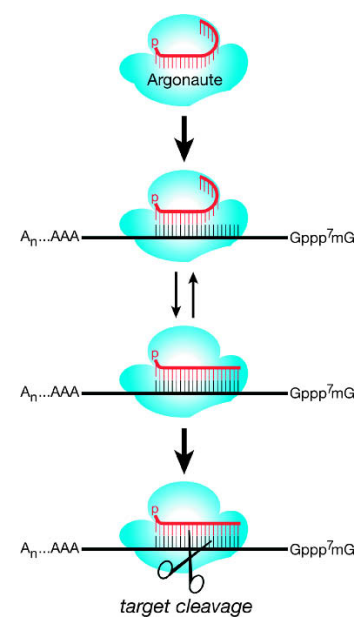

Figure 3. A two-state model for Argonaute function in RISC. end of the siRNA before RISC encounters its RNA target (Elbashir et al. 2001a,b; Haley and Zamore 2004; Martinez and Tuschl 2004). A 5' phosphate on the siRNA guide strand is required for an siRNA to function (Boutla et al. 2001; Nykänen et al. 2001; Chiu and Rana 2002; Schwarz et al. 2002; Liu et al. 2004a).

We envision the $5^{\prime}$ half of the small RNA guide to be bound to Argonaute protein in a quasi-helical shape. In other words, about half of the small RNA guide is proposed to be pre-organized for binding an RNA target. In contrast, the 3' half of the siRNA is predicted to be bound to Argonaute in a way that antagonizes its base pairing with the RNA target. Therefore, pairing of the $3^{\prime}$ half of the siRNA with the target RNA requires dislodging it from a binding pocket in Argonaute, perhaps the PAZ domain. Such pairing is required for efficient target cleavage but not the binding of small RNAs that repress translation. Energetically, the favorable energy produced by pairing the $3^{\prime}$ region of a small RNA with its target would be offset by the energy spent expelling these bases from their nook in Argonaute. The model helps explain why base pairs between the $3^{\prime}$ end of the siRNA and its RNA target influence $k_{\text {cat }}$ but not $K_{M}$ (Haley and Zamore 2004).

\section{Silencing modes}

In the translational repression pathway, small RNAs direct RISC to bind an mRNA and repress its translation into protein, rather than cleave it. Animal miRNAs typically, but not always, mediate translational repression rather than cleavage. In contrast, most plant miRNAs direct target RNA cleavage. In all of the well-studied examples of translational repression by animal miRNAs or by siRNAs, translational repression is a response to the binding of multiple small RNA-programmed RISCs to sites in the $3^{\prime}$ UTR of the mRNA target. In fact, the presence of multiple candidate sites in $3^{\prime}$ UTR sequences is a useful predictor of an mRNA being regulated by miRNA (Lewis et al. 2003). Complementarity between a small RNA and its RNA target helps determine if the small RNA directs target cleavage or represses mRNA translation, because an A-form helix must be formed with the target RNA at the center of an siRNA guide strand for cleavage to occur (Chiu and Rana 2003; Haley and Zamore 2004). In the absence of such a helix, as occurs when the central region of the small RNA cannot pair with bases in the target, translational repression may ensue. Translational repression occurs at some step after translational initiation, because the distribution of ribosomes along the length of the repressed mRNA is thus far indistinguishable from the same mRNA undergoing active translation (Olsen and Ambros 1999). A tantalizing proposal from Sharp and colleagues (cited in Ketting and Plasterk 2004) is that RISC somehow directs degradation of the nascent polypeptide, rather than simply stalling translational elongation. Both models are currently without experimental support.

Small RNAs can also direct the formation of repressive heterochromatin. The only complex thus far described 
for this pathway is the Schizosaccharomyces pombe RITS, a RISC-like complex that contains siRNA, an Argonaute protein (Ago1), the chromodomain protein Chp1, and Tas3, a protein of unknown function (Noma et al. 2004; Verdel et al. 2004). How the RITS directs modification of histones to promote the establishment of repressive heterochromatin is unknown. In fact, it is not known if the RITS binds the DNA of the targeted gene or simply binds nuclear RNA transcribed from the targeted DNA sequences. DsRNA targeting promoter sequences also trigger transcriptional silencing in plants (Mette et al. 2000). siRNA-directed transcriptional silencing via DNA methylation was recently reported in animals, too (Kawasaki and Taira 2004; Morris et al. 2004). The complexes that mediate these effects are not known, and such effects were not observed for long dsRNA in mouse oocytes (Svoboda et al. 2004).

If small RNAs mediate three distinct functions, are there three corresponding RNA silencing effector complexes? Current data suggest both yes and no. In human cells, only Ago2, of four closely related Argonaute proteins, contains the key amino acids thought to catalyze target RNA cleavage. But Ago2 is bifunctional, since it can both direct mRNA cleavage and repress translation. This discovery was made in an elegant experiment by Filipowicz and coworkers (Pillai et al. 2004). They fused human Ago2 to the small, basic RNA-binding N-peptide from bacteriophage $\lambda$. The fusion protein retained the capacity for small RNA-guided target RNA cleavage. Next, they placed multiple N-peptide-binding sites in the 3' UTR of a reporter mRNA and introduced both the Ago2 fusion protein and the reporter into human cells. The Ago2 fusion protein bound the 3' UTR sites through the N-peptide rather than via a small RNA guide and silenced reporter protein production without reducing reporter mRNA levels. Translational repression by the Ago2-N fusion protein resembled translational repression directed by small RNAs in that more than three binding sites were required to achieve robust repression. Thus, Ago2 can direct both cleavage and translational repression in this engineered system. Purified Ago2 alone suffices for small RNA-guided target cleavage (Liu et al. 2004a), but perhaps accessory proteins assist Ago2 in other functions like translational or transcriptional repression. In contrast, human Ago1-, Ago3-, or Ago4containing complexes cannot cleave (Liu et al. 2004a; Meister et al. 2004). Each of these three Argonaute proteins differs from Ago2 at one or more putative catalytic amino acids (Liu et al. 2004a). The function of human Agol remains to be determined, but Ago4 and perhaps Ago3 likely silence by repressing translation (Pillai et al. 2004).

Two of the five Drosophila Argonaute proteins, Agol and Ago2, are associated with RISCs capable of cleavage (Okamura et al. 2004), although we do not know if Drosophila Ago1- or Ago2-containing RISC can also cause translational repression. Current data suggest that Agol is the core component of miRNA-programmed RISCs and Ago2 is the core component of siRNA-programmed RISCs, implying that the assembly machinery restricts
miRNAs to bind Agol and siRNA to bind Ago2 in flies (Okamura et al. 2004). At odds with this simple view is the requirement for the Drosophila Argonaute protein, Aubergine, in both RNAi in vivo and RISC assembly in vitro (Kennerdell et al. 2002; Tomari et al. 2004a). Moreover, experiments using tagged, over-expressed human Argonaute proteins in cultured mammalian cells suggest that at least four human Argonaute proteins bind indiscriminately to miRNAs and siRNAs (Liu et al. 2004a; Meister et al. 2004). The worm Argonaute proteins RDE1 and ALG1/ALG2 provide a counter example. RDE1 is required for RNAi triggered by exogenous dsRNA, but plays little or no role in miRNA function (Tabara et al. 1999, 2002). The ALG1 and 2 proteins play no role in RNAi, but are essential for miRNA biogenesis and/or function (Grishok et al. 2001), likely because the ALG1 and 2 proteins bind miRNAs (Hutvágner et al. 2004).

Data from $S$. pombe suggest that Argonaute proteins might even be tri-functional. Translational repression has not yet been detected in fungi, but small RNAs direct both transcriptional and post-transcriptional silencing in $S$. pombe. Transcriptional silencing of large swaths of DNA occurs at the $S$. pombe centromere and the related mating-type locus. Transcription of these regions is blocked by the formation of repressive heterochromatin, which is enriched for Histone $\mathrm{H} 3$ methylated at Lys 9 (H3-K9) (Elgin and Grewal 2003). Small RNAs initiate the formation of heterochromatin in $S$. pombe, and the RNAi pathway is critical for building the $S$. pombe centromere (Verdel et al. 2004). Three "RNAi" genes are required for this process: RNA-dependent RNA polymerase (Rdp1), Dicer (Dcr1), and Argonaute (Ago1). Rdp1 is thought to amplify or produce the initial dsRNA trigger for centromeric silencing in $S$. pombe, Dcr1 is presumed to generate siRNAs from the trigger dsRNA, and Agol is a component of the RITS complex, the presumptive effector complex of siRNA-directed transcriptional silencing. The RNA silencing pathway may play a general role in the construction of centromeres, because Dicer is required for the formation of centromeric heterochromatin in cultured vertebrate cells (Fukagawa et al. 2004; Kanellopoulou et al. 2005).

Agol is the sole $S$. pombe Argonaute protein and is also required for dsRNA-triggered post-transcriptional silencing in this yeast (Sigova et al. 2004). PTGS in $S$. pombe also requires Rdp1, Dcr1, and siRNAs, like classical RNAi in worms. Thus, a single Argonaute protein can act in both transcriptional and post-transcriptional RNA silencing pathways. However, Tas3 and Chp1 are not required for PTGS, suggesting either that Agol is the sole protein required for $S$. pombe RNAi or that distinct TGS and PTGS complexes, both containing Ago1, coexist in $S$. pombe.

\section{Questions for the future}

Despite all we have learned about the mechanism of RNA silencing, many remarkably simple questions remain unanswered. Is there really an siRNA unwindase, a protein that uses ATP-energy to part the two siRNA 
strands? What proteins compose RISC in vivo, and what is the molecular function of each RISC component? How does RISC repress mRNA translation? How does it trigger changes in chromatin structure or DNA methylation? The more we explore RNA silencing, the more these pathways reveal their remarkable complexity. Which raises the most important question of all: What is the biological meaning of all this complexity?

\section{Acknowledgments}

We thank members of the Zamore laboratory for discussions and comments on the manuscript, and John Pham and Erik Sontheimer for sharing unpublished data. Y.T. is a recipient of a long-term fellowship from the Human Frontier Science Program. P.D.Z. is a W.M. Keck Foundation Young Scholar in Medical Research. This work was supported in part by grants from the National Institutes of Health to P.D.Z. (GM62862-01 and GM65236-01).

\section{References}

Amarzguioui, M. and Prydz, H. 2004. An algorithm for selection of functional siRNA sequences. Biochem. Biophys. Res. Commun. 316: 1050-1058.

Ambros, V., Bartel, B., Bartel, D.P., Burge, C.B., Carrington, J.C., Chen, X., Dreyfuss, G., Eddy, S.R., Griffiths-Jones, S., Marshall, M., et al. 2003. A uniform system for microRNA annotation. RNA 9: 277-279.

Aravin, A.A., Naumova, N.M., Tulin, A.V., Vagin, V.V., Rozovsky, Y.M., and Gvozdev, V.A. 2001. Double-stranded RNA-mediated silencing of genomic tandem repeats and transposable elements in the D. melanogaster germline. Curr. Biol. 11: 1017-1027.

Aravin, A.A., Lagos-Quintana, M., Yalcin, A., Zavolan, M., Marks, D., Snyder, B., Gaasterland, T., Meyer, J., and Tuschl, T. 2003. The small RNA profile during Drosophila melanogaster development. Dev. Cell 5: 337-350.

Aukerman, M.J. and Sakai, H. 2003. Regulation of flowering time and floral organ identity by a microRNA and its APETALA2-like target genes. Plant Cell 15: 2730-2741.

Aza-Blanc, P., Cooper, C.L., Wagner, K., Batalov, S., Deveraux, Q.L., and Cooke, M.P. 2003. Identification of modulators of TRAIL-induced apoptosis via RNAi-based phenotypic screening. Mol. Cell 12: 627-637.

Bao, N., Lye, K.W., and Barton, M.K. 2004. MicroRNA binding sites in Arabidopsis class III HD-ZIP mRNAs are required for methylation of the template chromosome. Dev. Cell 7: 653-662.

Basyuk, E., Suavet, F., Doglio, A., Bordonne, R., and Bertrand, E. 2003. Human let-7 stem-loop precursors harbor features of RNase III cleavage products. Nucleic Acids Res. 31: 65936597.

Baulcombe, D.C. 1996. RNA as a target and an initiator of posttranscriptional gene silencing in transgenic plants. Plant Mol. Biol. 32: 79-88.

- 2004. RNA silencing in plants. Nature 431: 356-363.

Bennasser, Y., Le, S.Y., Yeung, M.L., and Jeang, K.T. 2004. HIV-1 encoded candidate micro-RNAs and their cellular targets. Retrovirology 1: 43.

Bernstein, E., Caudy, A.A., Hammond, S.M., and Hannon, G.J. 2001. Role for a bidentate ribonuclease in the initiation step of RNA interference. Nature 409: 363-366.
Billy, E., Brondani, V., Zhang, H., Muller, U., and Filipowicz, W. 2001. Specific interference with gene expression induced by long, double-stranded RNA in mouse embryonal teratocarcinoma cell lines. Proc. Natl. Acad. Sci. 98: 14428-14433.

Boerjan, W., Bauw, G., Van Montagu, M., and Inze, D. 1994. Distinct phenotypes generated by overexpression and suppression of S-adenosyl-L-methionine synthetase reveal developmental patterns of gene silencing in tobacco. Plant Cell 6: 1401-1414.

Bohnsack, M.T., Czaplinski, K., and Gorlich, D. 2004. Exportin 5 is a Ran GTP-dependent dsRNA-binding protein that mediates nuclear export of pre-miRNAs. RNA 10: 185-191.

Boutla, A., Delidakis, C., Livadaras, I., Tsagris, M., and Tabler, M. 2001. Short 5'-phosphorylated double-stranded RNAs induce RNA interference in Drosophila. Curr. Biol. 11: 17761780 .

Bracht, J., Hunter, S., Eachus, R., Weeks, P., and Pasquinelli, A. 2004. Trans-splicing and polyadenylation of let-7 microRNA primary transcripts. RNA 10: 1586-1594.

Brennecke, J. and Cohen, S. 2003. Towards a complete description of the microRNA complement of animal genomes. $G e$ nome Biol. 4: 228.

Brennecke, J., Hipfner, D.R., Stark, A., Russell, R.B., and Cohen, S.M. 2003. bantam encodes a developmentally regulated microRNA that controls cell proliferation and regulates the proapoptotic gene hid in Drosophila. Cell 113: 25-36.

Cai, X., Hagedorn, C., and Cullen, B. 2004. Human microRNAs are processed from capped, polyadenylated transcripts that can also function as mRNAs. RNA 10: 1957-1966.

Catalanotto, C., Azzalin, G., Macino, G., and Cogoni, C. 2002. Involvement of small RNAs and role of the qde genes in the gene silencing pathway in Neurospora. Genes \& Dev. 16: 790-795.

Celotto, A.M. and Graveley, B.R. 2002. Exon-specific RNAi: A tool for dissecting the functional relevance of alternative splicing. RNA 8: 8-24.

Chang, S., Johnston Jr., R.J., Frokjaer-Jensen, C., Lockery, S., and Hobert, O. 2004. MicroRNAs act sequentially and asymmetrically to control chemosensory laterality in the nematode. Nature 430: 785-789.

Chapman, E.J., Prokhnevsky, A.I., Gopinath, K., Dolja, V.V., and Carrington, J.C. 2004. Viral RNA silencing suppressors inhibit the microRNA pathway at an intermediate step. Genes \& Dev. 18: 1179-1186.

Chen, X. 2004. A microRNA as a translational repressor of APETALA2 in Arabidopsis flower development. Science 303: 2022-2025.

Chen, C.Z., Li, L., Lodish, H.F., and Bartel, D.P. 2004. MicroRNAs modulate hematopoietic lineage differentiation. Science 303: 83-86.

Chiu, Y.-L. and Rana, T.M. 2002. RNAi in human cells: Basic structural and functional features of small interfering RNA. Mol. Cell 10: 549-561.

- 2003. siRNA function in RNAi: A chemical modification analysis. RNA 9: 1034-1048.

Clemens, J.C., Worby, C.A., Simonson-Leff, N., Muda, M., Maehama, T., Hemmings, B.A., and Dixon, J.E. 2000. Use of double-stranded RNA interference in Drosophila cell lines to dissect signal transduction pathways. Proc. Natl. Acad. Sci. 97: 6499-6503.

Cogoni, C. and Macino, G. 1999. Gene silencing in Neurospora crassa requires a protein homologous to RNA-dependent RNA polymerase. Nature 399: 166-169.

Cogoni, C., Irelan, J.T., Schumacher, M., Schmidhauser, T.J., Selker, E.U., and Macino, G. 1996. Transgene silencing of the al-1 gene in vegetative cells of Neurospora is mediated by 
a cytoplasmic effector and does not depend on DNA-DNA interactions or DNA methylation. EMBO J. 15: 3153-3163.

Dalmay, T., Hamilton, A., Rudd, S., Angell, S., and Baulcombe, D.C. 2000. An RNA-dependent RNA polymerase gene in Arabidopsis is required for posttranscriptional gene silencing mediated by a transgene but not by a virus. Cell 101: 543-553.

Denli, A.M., Tops, B.B., Plasterk, R.H., Ketting, R.F., and Hannon, G.J. 2004. Processing of primary microRNAs by the microProcessor complex. Nature 432: 231-235.

Djikeng, A., Shi, H., Tschudi, C., Shen, S., and Ullu, E. 2003. An siRNA ribonucleoprotein is found associated with polyribosomes in Trypanosoma brucei. RNA 9: 802-808.

Doench, J.G. and Sharp, P.A. 2004. Specificity of microRNA target selection in translational repression. Genes \& Dev 18: $504-511$.

Doench, J.G., Petersen, C.P., and Sharp, P.A. 2003. siRNAs can function as miRNAs. Genes \& Dev. 17: 438-442.

Doi, N., Zenno, S., Ueda, R., Ohki-Hamazaki, H., Ui-Tei, K., and Saigo, K. 2003. Short-interfering-RNA-mediated gene silencing in mammalian cells requires Dicer and eIF2C translation initiation factors. Curr. Biol. 13: 41-46.

Dostie, J., Mourelatos, Z., Yang, M., Sharma, A., and Dreyfuss, G. 2003. Numerous microRNPs in neuronal cells containing novel microRNAs. RNA 9: 180-186.

Dunoyer, P., Lecellier, C.H., Parizotto, E.A., Himber, C., and Voinnet, O. 2004. Probing the microRNA and small interfering RNA pathways with virus-encoded suppressors of RNA silencing. Plant Cell 16: 1235-1250.

Elbashir, S.M., Lendeckel, W., and Tuschl, T. 2001a. RNA interference is mediated by 21 - and 22-nucleotide RNAs. Genes \& Dev. 15: 188-200.

Elbashir, S.M., Martinez, J., Patkaniowska, A., Lendeckel, W., and Tuschl, T. 2001b. Functional anatomy of siRNAs for mediating efficient RNAi in Drosophila melanogaster embryo lysate. EMBO J. 20: 6877-6888.

Elgin, S.C. and Grewal, S.I. 2003. Heterochromatin: Silence is golden. Curr. Biol. 13: R895-R898.

Enright, A.J., John, B., Gaul, U., Tuschl, T., Sander, C., and Marks, D.S. 2003. MicroRNA targets in Drosophila. Genome Biol. 5: R1.

Finnegan, E.J., Margis, R., and Waterhouse, P.M. 2003. Posttranscriptional gene silencing is not compromised in the Arabidopsis CARPEL FACTORY (DICER-LIKE1) mutant, a homolog of Dicer-1 from Drosophila. Curr. Biol. 13: 236-240.

Fire, A., Xu, S., Montgomery, M.K., Kostas, S.A., Driver, S.E., and Mello, C.C. 1998. Potent and specific genetic interference by double-stranded RNA in Caenorhabditis elegans Nature 391: 806-811.

Freier, S.M., Burger, B.J., Alkema, D., Neilson, T., and Turner, D.H. 1983. Effects of 3 ' dangling end stacking on the stability of GGCC and CCGG double helices. Biochemistry 22: 6198-6206.

Fukagawa, T., Nogami, M., Yoshikawa, M., Ikeno, M., Okazaki, T., Takami, Y., Nakayama, T., and Oshimura, M. 2004. Dicer is essential for formation of the heterochromatin structure in vertebrate cells. Nat. Cell. Biol. 6: 784-791.

Gong, D. and Ferrell Jr., J.E. 2004. Picking a winner: New mechanistic insights into the design of effective siRNAs. Trends Biotechnol. 22: 451-454.

Gregory, R.I., Yan, K.P., Amuthan, G., Chendrimada, T., Doratotaj, B., Cooch, N., and Shiekhattar, R. 2004. The microProcessor complex mediates the genesis of microRNAs. $\mathrm{Na}$ ture 432: 235-240.

Grishok, A., Tabara, H., and Mello, C. 2000. Genetic requirements for inheritance of RNAi in C. elegans. Science 287:
2494-2497.

Grishok, A., Pasquinelli, A.E., Conte, D., Li, N., Parrish, S., Ha, I., Baillie, D.L., Fire, A., Ruvkun, G., and Mello, C.C. 2001. Genes and mechanisms related to RNA interference regulate expression of the small temporal RNAs that control C. elegans developmental timing. Cell 106: 23-34.

Guo, S. and Kemphues, K.J. 1995. par-1, a gene required for establishing polarity in C. elegans embryos, encodes a putative Ser/Thr kinase that is asymmetrically distributed. Cell 81: 611-620.

Haley, B. and Zamore, P.D. 2004. Kinetic analysis of the RNAi enzyme complex. Nat. Struct. Mol. Biol. 11: 599-606.

Hall, I.M., Shankaranarayana, G.D., Noma, K.-I., Ayoub, N., Cohen, A., and Grewal, S.I.S. 2002. Establishment and maintenance of a heterochromatin domain. Science 297: 22322237.

Hamilton, A.J. and Baulcombe, D.C. 1999. A species of small antisense RNA in posttranscriptional gene silencing in plants. Science 286: 950-952.

Hammond, S.M., Bernstein, E., Beach, D., and Hannon, G.J. 2000. An RNA-directed nuclease mediates post-transcriptional gene silencing in Drosophila cells. Nature 404: 293 296.

Hammond, S.M., Boettcher, S., Caudy, A.A., Kobayashi, R., and Hannon, G.J. 2001. Argonaute2, a link between genetic and biochemical analyses of RNAi. Science 293: 1146-1150.

Han, J., Lee, Y., Yeom, K.H., Kim, Y.K., Jin, H., and Kim, V.N. 2004. The Drosha-DGCR8 complex in primary microRNA processing. Genes \& Dev. 18: 3016-3027.

Hohjoh, H. 2004. Enhancement of RNAi activity by improved siRNA duplexes. FEBS Lett. 557: 193-198.

Holen, T., Amarzguioui, M., Wiiger, M.T., Babaie, E., and Prydz, H. 2002. Positional effects of short interfering RNAs targeting the human coagulation trigger Tissue Factor. Nucleic Acids Res. 30: 1757-1766.

Hutvágner, G. and Zamore, P.D. 2002. A microRNA in a multiple-turnover RNAi enzyme complex. Science 297: 20562060.

Hutvágner, G., McLachlan, J., Pasquinelli, A.E., Balint, É., Tuschl, T., and Zamore, P.D. 2001. A cellular function for the RNA-interference enzyme Dicer in the maturation of the let-7 small temporal RNA. Science 293: 834-838.

Hutvágner, G., Simard, M.J., Mello, C.C., and Zamore, P.D. 2004. Sequence-specific inhibition of small RNA function. PLOS Biol. 2: 465-475.

Ishizuka, A., Siomi, M.C., and Siomi, H. 2002. A Drosophila fragile $X$ protein interacts with components of RNAi and ribosomal proteins. Genes \& Dev. 16: 2497-2508.

Jackson, A.L., Bartz, S.R., Schelter, J., Kobayashi, S.V., Burchard, J., Mao, M., Li, B., Cavet, G., and Linsley, P.S. 2003. Expression profiling reveals off-target gene regulation by RNAi. Nat. Biotechnol. 21: 635-637.

Johnston, R.J. and Hobert, O. 2003. A microRNA controlling left/right neuronal asymmetry in Caenorhabditis elegans Nature 426: 845-849.

Jorgensen, R.A. 2003. Sense cosuppression in plants: Past, present, and future. In RNAi: A guide to gene silencing (ed. G.J. Hannon), pp. 5-22. Cold Spring Harbor Laboratory Press, Cold Spring Harbor, NY.

Kanellopoulou, C., Muljo, S.A., Kung, A.L., Ganesan, S., Drapkin, R., Jenuwein, T., Livingston, D.M., and Rajewsky, K. 2005. Dicer-deficient mouse embryonic stem cells are defective in differentiation and centromeric silencing. Genes \& Dev. 19: 489-501.

Kawasaki, H. and Taira, K. 2004. Induction of DNA methylation and gene silencing by short interfering RNAs in human 
cells. Nature 431: 211-217.

Kennerdell, J.R. and Carthew, R.W. 1998. Use of dsRNA-mediated genetic interference to demonstrate that frizzled and frizzled 2 act in the wingless pathway. Cell 95: 1017-1026.

Kennerdell, J.R., Yamaguchi, S., and Carthew, R.W. 2002. RNAi is activated during Drosophila oocyte maturation in a manner dependent on aubergine and spindle-E. Genes \& Dev. 16: $1884-1889$.

Ketting, R.F. and Plasterk, R.H. 2004. What's new about RNAi? Meeting on siRNAs and miRNAs. EMBO Rep. 5: 762-765.

Ketting, R.F., Fischer, S.E., Bernstein, E., Sijen, T., Hannon, G.J., and Plasterk, R.H. 2001. Dicer functions in RNA interference and in synthesis of small RNA involved in developmental timing in C. elegans. Genes \& Dev. 15: 2654-2659.

Khvorova, A., Reynolds, A., and Jayasena, S.D. 2003. Functional siRNAs and miRNAs exhibit strand bias. Cell 115: 209-216.

Knight, S.W. and Bass, B.L. 2001. A role for the RNase III enzyme DCR-1 in RNA interference and germ line development in Caenorhabditis elegans. Science 293: 2269-2271.

Krol, J., Sobczak, K., Wilczynska, U., Drath, M., Jasinska, A., Kaczynska, D., and Krzyzosiak, W.J. 2004. Structural features of microRNA (miRNA) precursors and their relevance to miRNA biogenesis and small interfering RNA/short hairpin RNA design. J. Biol. Chem. 279: 42230-42239.

Kurihara, Y. and Watanabe, Y. 2004. Arabidopsis micro-RNA biogenesis through Dicer-like 1 protein functions. Proc. Natl. Acad. Sci. 101: 12753-12758.

Lagos-Quintana, M., Rauhut, R., Lendeckel, W., and Tuschl, T. 2001. Identification of novel genes coding for small expressed RNAs. Science 294: 853-858.

Lagos-Quintana, M., Rauhut, R., Yalcin, A., Meyer, J., Lendeckel, W., and Tuschl, T. 2002. Identification of tissue-specific microRNAs from mouse. Curr. Biol. 12: 735-739.

Lagos-Quintana, M., Rauhut, R., Meyer, J., Borkhardt, A., and Tuschl, T. 2003. New microRNAs from mouse and human. RNA 9: 175-179.

Lai, E.C. 2002. Micro RNAs are complementary to 3' UTR sequence motifs that mediate negative post-transcriptional regulation. Nat. Genet. 30: 363-364.

Lakatos, L., Szittya, G., Silhavy, D., and Burgyan, J. 2004. Molecular mechanism of RNA silencing suppression mediated by p19 protein of tombusviruses. EMBO J. 23: 876-884.

Landthaler, M., Yalcin, A., and Tuschl, T. 2004. The human DiGeorge syndrome critical region gene 8 and Its $D$. melanogaster homolog are required for miRNA biogenesis. Curr. Biol. 14: 2162-2167.

Lau, N.C., Lim, L.P., Weinstein, E.G., and Bartel, D.P. 2001. An abundant class of tiny RNAs with probable regulatory roles in Caenorhabditis elegans. Science 294: 858-862.

Lee, R.C. and Ambros, V. 2001. An extensive class of small RNAs in Caenorhabditis elegans. Science 294: 862-864.

Lee, R.C., Feinbaum, R.L., and Ambros, V. 1993. The C. elegans heterochronic gene lin-4 encodes small RNAs with antisense complementarity to lin-14. Cell 75: 843-854.

Lee, Y., Jeon, K., Lee, J.T., Kim, S., and Kim, V.N. 2002. MicroRNA maturation: Stepwise processing and subcellular localization. EMBO J. 21: 4663-4670.

Lee, Y., Ahn, C., Han, J., Choi, H., Kim, J., Yim, J., Lee, J., Provost, P., Radmark, O., Kim, S., et al. 2003. The nuclear RNase III Drosha initiates microRNA processing. Nature 425: 415-419.

Lee, Y., Kim, M., Han, J., Yeom, K.H., Lee, S., Baek, S.H., and Kim, V.N. 2004a. MicroRNA genes are transcribed by RNA polymerase II. EMBO J. 23: 4051-4060.

Lee, Y.S., Nakahara, K., Pham, J.W., Kim, K., He, Z., Sontheimer, E.J., and Carthew, R.W. 2004b. Distinct roles for Dro- sophila Dicer-1 and Dicer-2 in the siRNA/miRNA silencing pathways. Cell 117: 69-81.

Lewis, B., Shih, I., Jones-Rhoades, M., Bartel, D., and Burge, C. 2003. Prediction of mammalian microRNA targets. Cell 115: 787-798.

Lim, L.P., Glasner, M.E., Yekta, S., Burge, C.B., and Bartel, D.P. 2003a. Vertebrate microRNA genes. Science 299: 1540.

Lim, L.P., Lau, N.C., Weinstein, E.G., Abdelhakim, A., Yekta, S., Rhoades, M.W., Burge, C.B., and Bartel, D.P. 2003b. The microRNAs of Caenorhabditis elegans. Genes \& Dev. 17: 991-1008.

Lingel, A., Simon, B., Izaurralde, E., and Sattler, M. 2003. Structure and nucleic-acid binding of the Drosophila Argonaute 2 PAZ domain. Nature 426: 465-469.

- 2004. Nucleic acid 3'-end recognition by the Argonaute2 PAZ domain. Nat. Struct. Mol. Biol. 11: 576-577.

Lipardi, C., Wei, Q., and Paterson, B.M. 2001. RNAi as random degradative PCR. siRNA primers convert mRNA into dsRNAs that are degraded to generate new siRNAs. Cell 107: 297-307.

Liu, Q., Rand, T.A., Kalidas, S., Du, F., Kim, H.E., Smith, D.P., and Wang, X. 2003. R2D2, a bridge between the initiation and effector steps of the Drosophila RNAi pathway. Science 301: 1921-1925.

Liu, J., Carmell, M.A., Rivas, F.V., Marsden, C.G., Thomson, J.M., Song, J.J., Hammond, S.M., Joshua-Tor, L., and Hannon, G.J. 2004a. Argonaute2 is the catalytic engine of mammalian RNAi. Science 305: 1437-1441.

Liu, J., He, Y., Amasino, R., and Chen, X. 2004b. siRNAs targeting an intronic transposon in the regulation of natural flowering behavior in Arabidopsis. Genes \& Dev. 18: 2873 2878.

Llave, C., Kasschau, K.D., Rector, M.A., and Carrington, J.C. 2002a. Endogenous and silencing-associated small RNAs in plants. Plant Cell 14: 1605-1619.

Llave, C., Xie, Z., Kasschau, K.D., and Carrington, J.C. 2002b. Cleavage of Scarecrow-Like mRNA targets directed by a class of Arabidopsis miRNA. Science 297: 2053-2056.

Lund, E., Guttinger, S., Calado, A., Dahlberg, J.E., and Kutay, U. 2004. Nuclear export of microRNA precursors. Science 303: 95-98.

Ma, J.B., Ye, K., and Patel, D.J. 2004. Structural basis for overhang-specific small interfering RNA recognition by the PAZ domain. Nature 429: 318-322.

Makeyev, E.V. and Bamford, D.H. 2002. Cellular RNA-dependent RNA polymerase involved in posttranscriptional gene silencing has two distinct activity modes. Mol. Cell 10: 1417-1427.

Mallory, A.C., Dugas, D.V., Bartel, D.P., and Bartel, B. 2004. MicroRNA regulation of NAC-domain targets is required for proper formation and separation of adjacent embryonic, vegetative, and floral organs. Curr. Biol. 14: 1035-1046.

Martinez, J. and Tuschl, T. 2004. RISC is a $5^{\prime}$ phosphomonoester-producing RNA endonuclease. Genes \& Dev. 18: 975980.

Martinez, J., Patkaniowska, A., H, H.U., Lührmann, R., and Tuschl, T. 2002. Single stranded antisense siRNA guide target RNA cleavage in RNAi. Cell 110: 563-574.

Meister, G., Landthaler, M., Patkaniowska, A., Dorsett, Y., Teng, G., and Tuschl, T. 2004. Human Argonaute2 mediates RNA cleavage targeted by miRNAs and siRNAs. Mol. Cell 15: $185-197$.

Mette, M.F., Aufsatz, W., van der Winden, J., Matzke, M.A., and Matzke, A.J. 2000. Transcriptional silencing and promoter methylation triggered by double-stranded RNA. EMBO $\mathrm{J}$. 19: 5194-5201. 
Mochizuki, K., Fine, N.A., Fujisawa, T., and Gorovsky, M.A. 2002. Analysis of a piwi-related gene implicates small RNAs in genome rearrangement in Tetrahymena. Cell 110: 689-699.

Montgomery, M.K. and Fire, A. 1998. Double-stranded RNA as a mediator in sequence-specific genetic silencing and co-suppression. Trends Genet. 14: 255-258.

Morris, K.V., Chan, S.W., Jacobsen, S.E., and Looney, D.J. 2004. Small interfering RNA-induced transcriptional gene silencing in human cells. Science 305: 1289-1292.

Mourelatos, Z., Dostie, J., Paushkin, S., Sharma, A.K., Charroux, B., Abel, L., Rappsilber, J., Mann, M., and Dreyfuss, G. 2002. miRNPs: A novel class of ribonucleoproteins containing numerous microRNAs. Genes \& Dev. 16: 720-728.

Mourrain, P., Beclin, C., Elmayan, T., Feuerbach, F., Godon, C., Morel, J.B., Jouette, D., Lacombe, A.M., Nikic, S., Picault, N., et al. 2000. Arabidopsis SGS2 and SGS3 genes are required for posttranscriptional gene silencing and natural virus resistance. Cell 101: 533-542.

Naito, Y., Yamada, T., Ui-Tei, K., Morishita, S., and Saigo, K. 2004. siDirect: Highly effective, target-specific siRNA design software for mammalian RNA interference. Nucleic Acids Res. 32 (Web Server issue): W124-W129.

Noma, K., Sugiyama, T., Cam, H., Verdel, A., Zofall, M., Jia, S., Moazed, D., and Grewal, S.I. 2004. RITS acts in cis to promote RNA interference-mediated transcriptional and posttranscriptional silencing. Nat. Genet. 36: 1174-1180.

Nykänen, A., Haley, B., and Zamore, P.D. 2001. ATP requirements and small interfering RNA structure in the RNA interference pathway. Cell 107: 309-321.

Okamura, K., Ishizuka, A., Siomi, H., and Siomi, M.C. 2004. Distinct roles for Argonaute proteins in small RNA-directed RNA cleavage pathways. Genes \& Dev. 18: 1655-1666.

Olsen, P.H. and Ambros, V. 1999. The lin-4 regulatory RNA controls developmental timing in Caenorhabditis elegans by blocking LIN-14 protein synthesis after the initiation of translation. Dev. Biol. 216: 671-680.

Palatnik, J.F., Allen, E., Wu, X., Schommer, C., Schwab, R., Carrington, J.C., and Weigel, D. 2003. Control of leaf morphogenesis by microRNAs. Nature 425: 257-263.

Papp, I., Mette, M.F., Aufsatz, W., Daxinger, L., Schauer, S.E., Ray, A., van der Winden, J., Matzke, M., and Matzke, A.J. 2003. Evidence for nuclear processing of plant micro RNA and short interfering RNA precursors. Plant Physiol. 132: $1382-1390$.

Parizotto, E., Dunoyer, P., Rahm, N., Himber, C., and Voinnet, O. 2004. In vivo investigation of the transcription, processing, endonucleolytic activity, and functional relevance of the spatial distribution of a plant miRNA. Genes \& Dev. 18: $2237-2242$.

Park, W., Li, J., Song, R., Messing, J., and Chen, X. 2002. CARPEL FACTORY, a Dicer homolog, and HEN1, a novel protein, act in microRNA metabolism in Arabidopsis thaliana. Curr. Biol. 12: 1484-1495.

Parker, J.S., Roe, S.M., and Barford, D. 2004. Crystal structure of a PIWI protein suggests mechanisms for siRNA recognition and slicer activity. EMBO J. 23: 4727-4737.

Pasquinelli, A.E., Reinhart, B.J., Slack, F., Martindale, M.Q., Kuroda, M.I., Maller, B., Hayward, D.C., Ball, E.E., Degnan, B., Muller, P., et al. 2000. Conservation of the sequence and temporal expression of let-7 heterochronic regulatory RNA. Nature 408: 86-89.

Pfeffer, S., Zavolan, M., Grasser, F.A., Chien, M., Russo, J.J., Ju, J., John, B., Enright, A.J., Marks, D., Sander, C., et al. 2004. Identification of virus-encoded microRNAs. Science 304: 734-736.

Pham, J.W., Pellino, J.L., Lee, Y.S., Carthew, R.W., and Sonthei- mer, E.J. 2004. A Dicer-2-dependent 80 complex cleaves targeted mRNAs during RNAi in Drosophila. Cell 117: 83-94.

Pillai, R.S., Artus, C.G., and Filipowicz, W. 2004. Tethering of human Ago proteins to mRNA mimics the miRNA-mediated repression of protein synthesis. RNA 10: 1518-1525.

Reinhart, B.J. and Bartel, D.P. 2002. Small RNAs correspond to centromere heterochromatic repeats. Science 297: 1831.

Reinhart, B.J., Slack, F.J., Basson, M., Pasquinelli, A.E., Bettinger, J.C., Rougvie, A.E., Horvitz, H.R., and Ruvkun, G. 2000. The 21-nucleotide let-7 RNA regulates developmental timing in Caenorhabditis elegans. Nature 403: 901-906.

Reinhart, B.J., Weinstein, E.G., Rhoades, M.W., Bartel, B., and Bartel, D.P. 2002. MicroRNAs in plants. Genes \& Dev. 16: $1616-1626$.

Reynolds, A., Leake, D., Boese, Q., Scaringe, S., Marshall, W.S., and Khvorova, A. 2004. Rational siRNA design for RNA interference. Nat. Biotechnol. 22: 326-330.

Roignant, J.Y., Carre, C., Mugat, B., Szymczak, D., Lepesant, J.A., and Antoniewski, C. 2003. Absence of transitive and systemic pathways allows cell-specific and isoform-specific RNAi in Drosophila. RNA 9: 299-308.

Saxena, S., Jonsson, Z.O., and Dutta, A. 2003. Small RNAs with imperfect match to endogenous mRNA repress translation: Implications for off-target activity of siRNA in mammalian cells. J. Biol. Chem. 278: 44312-44319.

Schiebel, W., Haas, B., Marinkovic, S., Klanner, A., and Sanger, H.L. 1993a. RNA-directed RNA polymerase from tomato leaves. I. Purification and physical properties. J. Biol. Chem. 268: 11851-11857.

. 1993b. RNA-directed RNA polymerase from tomato leaves. II. Catalytic in vitro properties. I. Biol. Chem. 268: $11858-11867$.

Schiebel, W., Pelissier, T., Riedel, L., Thalmeir, S., Schiebel, R., Kempe, D., Lottspeich, F., Sanger, H.L., and Wassenegger, M. 1998. Isolation of an RNA-directed RNA polymerase-specific cDNA clone from tomato. Plant Cell 10: 2087-2101.

Schramke, V. and Allshire, R. 2003. Hairpin RNAs and retrotransposon LTRs effect RNAi and chromatin-based gene silencing. Science 301: 1069-1074.

Schwarz, D.S., Hutvágner, G., Haley, B., and Zamore, P.D. 2002. Evidence that siRNAs function as guides, not primers, in the Drosophila and human RNAi pathways. Mol. Cell 10: 537548.

Schwarz, D.S., Hutvágner, G., Du, T., Xu, Z., Aronin, N., and Zamore, P.D. 2003. Asymmetry in the assembly of the RNAi enzyme complex. Cell 115: 199-208.

Schwarz, D.S., Tomari, Y., and Zamore, P.D. 2004. The RNAinduced silencing complex is a $\mathrm{Mg}^{2+}$-dependent endonuclease. Curr. Biol. 14: 787-791.

Shi, H., Diikeng, A., Tschudi, C., and Ullu, E. 2004. Argonaute protein in the early divergent eukaryote Trypanosoma brucei: Control of small interfering RNA accumulation and retroposon transcript abundance. Mol. Cell. Biol. 24: 420-427.

Shiu, P.K., Raju, N.B., Zickler, D., and Metzenberg, R.L. 2001. Meiotic silencing by unpaired DNA. Cell 107: 905-916.

Sigova, A., Rhind, N., and Zamore, P.D. 2004. A single Argonaute protein mediates both transcriptional and posttranscriptional silencing in Schizosaccharomyces pombe. Genes \& Dev. 18: 2359-2367.

Sijen, T., Fleenor, J., Simmer, F., Thijssen, K.L., Parrish, S., Timmons, L., Plasterk, R.H., and Fire, A. 2001. On the role of RNA amplification in dsRNA-triggered gene silencing. Cell 107: 465-476.

Silva, J.M., Sachidanandam, R., and Hannon, G.J. 2003. Free energy lights the path toward more effective RNAi. Nat. Genet. 35: 303-305. 
Smardon, A., Spoerke, J., Stacey, S., Klein, M., Mackin, N., and Maine, E. 2000. EGO-1 is related to RNA-directed RNA polymerase and functions in germ-line development and RNA interference in C. elegans. Curr. Biol. 10: 169-178.

Song, J.J., Liu, J., Tolia, N.H., Schneiderman, J., Smith, S.K., Martienssen, R.A., Hannon, G.J., and Joshua-Tor, L. 2003. The crystal structure of the Argonaute 2 PAZ domain reveals an RNA binding motif in RNAi effector complexes. Nat. Struct. Biol. 10: 1026-1032.

Song, J.J., Smith, S.K., Hannon, G.J., and Joshua-Tor, L. 2004. Crystal structure of Argonaute and its implications for RISC slicer activity. Science 305: 1434-1437.

Stark, A., Brennecke, J., Russel, R., and Cohen, S. 2003. Identification of Drosophila microRNA targets. PLoS Biol. 1: 1-13.

Svoboda, P., Stein, P., Filipowicz, W., and Schultz, R. 2004. Lack of homologous sequence-specific DNA methylation in response to stable dsRNA expression in mouse oocytes. Nucleic Acids Res. 32: 3601-3606.

Tabara, H., Grishok, A., and Mello, C.C. 1998. RNAi in C. elegans: Soaking in the genome sequence. Science 282: 430-431.

Tabara, H., Sarkissian, M., Kelly, W.G., Fleenor, J., Grishok, A., Timmons, L., Fire, A., and Mello, C.C. 1999. The rde-1 gene, RNA interference, and transposon silencing in C. elegans. Cell 99: 123-132.

Tabara, H., Yigit, E., Siomi, H., and Mello, C.C. 2002. The dsRNA binding protein RDE-4 interacts with RDE-1, DCR1, and a DexH-box helicase to direct RNAi in C. elegans. Cell 109: 861-871.

Tahbaz, N., Kolb, F.A., Zhang, H., Jaronczyk, K., Filipowicz, W., and Hobman, T.C. 2004. Characterization of the interactions between mammalian PAZ PIWI domain proteins and Dicer. EMBO Rep. 5: 189-194.

Tang, G., Reinhart, B.J., Bartel, D.P., and Zamore, P.D. 2003. A biochemical framework for RNA silencing in plants. Genes \& Dev. 17: 49-63.

Timmons, L. and Fire, A. 1998. Specific interference by ingested dsRNA. Nature 395: 854.

Tomari, Y., Du, T., Haley, B., Schwarz, D.S., Bennett, R., Cook, H.A., Koppetsch, B.S., Theurkauf, W.E., and Zamore, P.D. 2004a. RISC assembly defects in the Drosophila RNAi mutant armitage. Cell 116: 831-841.

Tomari, Y., Matranga, C., Haley, B., Martinez, N., and Zamore, P.D. 2004b. A protein sensor for siRNA asymmetry. Science 306: $1377-1380$.

Ui-Tei, K., Naito, Y., Takahashi, F., Haraguchi, T., OhkiHamazaki, H., Juni, A., Ueda, R., and Saigo, K. 2004. Guidelines for the selection of highly effective siRNA sequences for mammalian and chick RNA interference. Nucleic Acids Res. 32: 936-948.

Vaistij, F.E., Jones, L., and Baulcombe, D.C. 2002. Spreading of RNA targeting and DNA methylation in RNA silencing requires transcription of the target gene and a putative RNAdependent RNA polymerase. Plant Cell 14: 857-867.

Vargason, J.M., Szittya, G., Burgyan, J., and Tanaka Hall, T.M. 2003. Size selective recognition of siRNA by an RNA silencing suppressor. Cell 115: 799-811.

Vazquez, F., Vaucheret, H., Rajagopalan, R., Lepers, C., Gasciolli, V., Mallory, A.C., Hilbert, J.L., Bartel, D.P., and Crété, P. 2004. Endogenous trans-acting siRNAs regulate the accumulation of Arabidopsis mRNAs. Mol. Cell 16: 69-79.

Verdel, A., Jia, S., Gerber, S., Sugiyama, T., Gygi, S., Grewal, S.I., and Moazed, D. 2004. RNAi-mediated targeting of heterochromatin by the RITS complex. Science 303: 672-676.

Voinnet, O. and Baulcombe, D.C. 1997. Systemic signalling in gene silencing. Nature 389: 553.

Voinnet, O., Vain, P., Angell, S., and Baulcombe, D.C. 1998.
Systemic spread of sequence-specific transgene RNA degradation in plants is initiated by localized introduction of ectopic promoterless DNA. Cell 95: 177-187.

Volpe, T.A., Kidner, C., Hall, I.M., Teng, G., Grewal, S.I.S., and Martienssen, R.A. 2002. Regulation of heterochromatic silencing and histone H3 lysine-9 methylation by RNAi. Science 297: 1833-1837.

Waterhouse, P.M., Graham, M.W., and Wang, M.B. 1998. Virus resistance and gene silencing in plants can be induced by simultaneous expression of sense and antisense RNA. Proc. Natl. Acad. Sci. 95: 13959-13964.

Xia, T., Mathews, D.H., and Turner, D.H. 2001. Thermodynamics of RNA Secondary Structure Formation. In RNA (eds. D. Soll, S. Nishimura, and P.B. Moore), pp. 21-48. Pergamon, Oxford.

Xie, Z., Kasschau, K.D., and Carrington, J.C. 2003. Negative feedback regulation of Dicer-Like1 in Arabidopsis by microRNA-guided mRNA degradation. Curr. Biol. 13: 784-789.

Xie, Z., Johansen, L.K., Gustafson, A.M., Kasschau, K.D., Lellis, A.D., Zilberman, D., Jacobsen, S.E., and Carrington, J.C. 2004. Genetic and functional diversification of small RNA pathways in plants. PLOS Biol. 2: E104.

Yan, K.S., Yan, S., Farooq, A., Han, A., Zeng, L., and Zhou, M.M. 2003. Structure and conserved RNA binding of the PAZ domain. Nature 426: 468-474.

Ye, K., Malinina, L., and Patel, D.J. 2003. Recognition of small interfering RNA by a viral suppressor of RNA silencing. $\mathrm{Na}$ ture 426: 874-878.

Yekta, S., Shih, I.H., and Bartel, D.P. 2004. MicroRNA-directed cleavage of HOXB8 mRNA. Science 304: 594-596.

Yi, R., Qin, Y., Macara, I.G., and Cullen, B.R. 2003. Exportin-5 mediates the nuclear export of pre-microRNAs and short hairpin RNAs. Genes \& Dev. 17: 3011-3016.

Yiu, S.M., Wong, P.W., Lam, T.W., Mui, Y.C., Kung, H.F., Lin, M., and Cheung, Y.T. 2005. Filtering of ineffective siRNAs and improved siRNA design tool. Bioinformatics 21: 144151.

Yoo, B.C., Kragler, F., Varkonyi-Gasic, E., Haywood, V., ArcherEvans, S., Lee, Y.M., Lough, T.J., and Lucas, W.J. 2004. A systemic small RNA signaling system in plants. Plant Cell 16: $1979-2000$.

Zamore, P.D. 2001. RNA interference: Listening to the sound of silence. Nat. Struct. Biol. 8: 746-750.

Zamore, P.D., Tuschl, T., Sharp, P.A., and Bartel, D.P. 2000. RNAi: Double-stranded RNA directs the ATP-dependent cleavage of mRNA at 21 to 23 nucleotide intervals. Cell 101: 25-33.

Zeng, Y. and Cullen, B.R. 2003. Sequence requirements for micro RNA processing and function in human cells. RNA 9: $112-123$.

2004. Structural requirements for pre-microRNA binding and nuclear export by Exportin 5. Nucleic Acids Res. 32: 4776-4785.

Zeng, Y., Yi, R., and Cullen, B.R. 2003. MicroRNAs and small interfering RNAs can inhibit mRNA expression by similar mechanisms. Proc. Natl. Acad. Sci. 100: 9779-9784.

Zhang, H., Kolb, F.A., Brondani, V., Billy, E., and Filipowicz, W. 2002. Human Dicer preferentially cleaves dsRNAs at their termini without a requirement for ATP. EMBO J. 21: 58755885.

Zhang, H., Kolb, F., Jaskiewicz, L., Westhof, E., and Filipowicz, W. 2004. Single processing center models for human Dicer and bacterial RNase III. Cell 118: 57-68.

Zilberman, D., Cao, X., and Jacobsen, S.E. 2003. ARGONAUTE4 control of locus-specific siRNA accumulation and DNA and histone methylation. Science 299: 716-719 


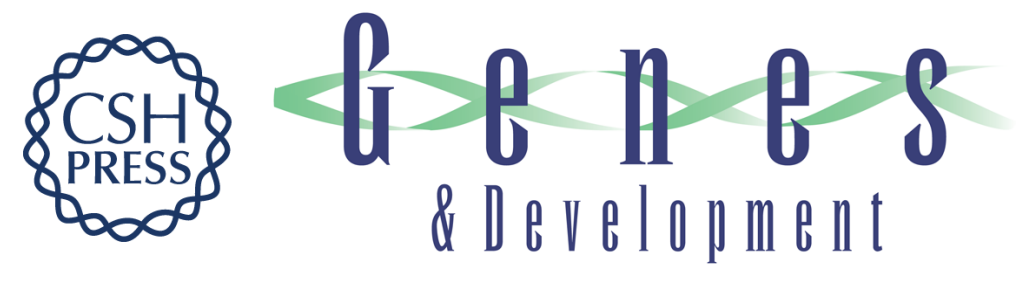

\section{Perspective: machines for RNAi}

Yukihide Tomari and Phillip D. Zamore

Genes Dev. 2005, 19:

Access the most recent version at doi:10.1101/gad.1284105

\section{Related Content A novel class of small RNAs in mouse spermatogenic cells Shane T. Grivna, Ergin Beyret, Zhong Wang, et al. Genes Dev. UNKNOWN , 2006 20: 1709-1714 Identification and characterization of two novel classes of small RNAs in the mouse germline: retrotransposon-derived siRNAs in oocytes and germline small RNAs in testes Toshiaki Watanabe, Atsushi Takeda, Tomoyuki Tsukiyama, et al. Genes Dev. UNKNOWN , 2006 20: 1732-1743 \\ References This article cites 181 articles, 85 of which can be accessed free at: http://genesdev.cshlp.org/content/19/5/517.full.html\#ref-list-1 \\ Articles cited in: http://genesdev.cshlp.org/content/19/5/517.full.html\#related-urls \\ License \\ Email Alerting
Service Receive free email alerts when new articles cite this article - sign up in the box at the top right corner of the article or click here.}

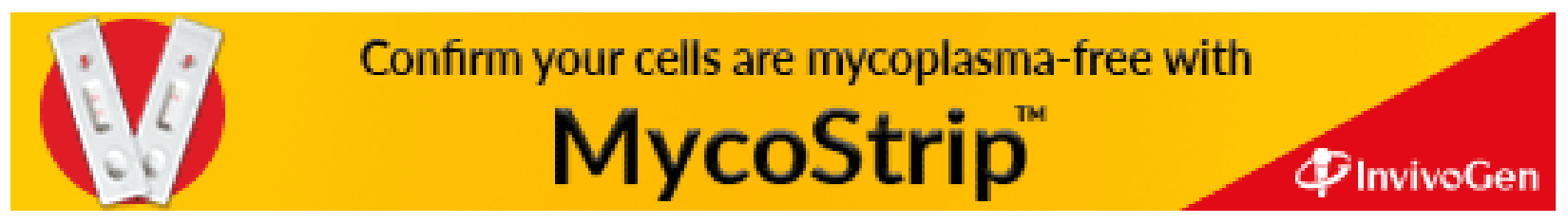

